Article

\title{
Man up! Masculinity and (Homo)sexuality in René Depestre's Transatlantic World
}

\author{
Jacqueline Couti $^{1, *}$ and Jason C. Grant ${ }^{2}$ \\ 1 Department of Classical and European Studies, Rice University, Houston, TX 77005, USA \\ 2 Department of Romance Languages and Literatures, University of Michigan, Ann Arbor, MI 48109, USA; \\ jcgrant@umich.edu \\ * Correspondence: jacqueline.couti@rice.edu
}

Received: 8 July 2019; Accepted: 10 September 2019; Published: 16 September 2019

\begin{abstract}
The question of homosexuality in Francophone Caribbean literature is often overlooked. However, the ways in which the Haitian René Depestre's Le mât de cocagne (The Festival of the Greasy Pole, 1979) and "Blues pour une tasse de thé vert" ("Blues for a Cup of Green Tea"), a short story from the collection Eros dans un train chinois (Eros on a Chinese Train, 1990) portray homoeroticism and homosexuality begs further study. In these texts, the study of the violence that surrounds the representation of sexuality reveals the sociopolitical implications of erotic and racial images in a French transatlantic world. Hence, the proposed essay "Man up!" interrogates a (Black) hegemonic masculinity inherited from colonialism and the homophobia it generates. This masculinity prescribes normative traits that frequently appear toxic as it thrives on hypersexuality and brute force. When these two traits become associated with violence and homoeroticism, however, they threaten this very masculinity. Initially, Depestre valorizes "solar eroticism," a French Caribbean expression of a Black sexuality, free and joyful, and "geolibertinage," its transnational and global expression. Namely, his novel and short story sing a hegemonic and polyamorous heterosexuality, respectively, in a postcolonial milieu (Haiti) and a diasporic space (Paris). The misadventures of his male characters suggest that eroticism in transatlantic spaces has more to do with Thanatos (death) than Eros (sex). Though Depestre formally explores the construction of the other and the mechanisms of racism and oppression in essays, he also tackles these themes in his fictional work. Applying Caribbean feminist and gendered lenses to his fiction bring to light the intricate bonds between racism, sexism and homophobia. Such a framework reveals the many facets of patriarchy and its mechanism of control.
\end{abstract}

Keywords: French Caribbean; Haiti; masculinity; homosexuality; eroticism; gender; sexuality

The thorny question of homosexuality in Francophone Caribbean literature merits further examination than it has received thus far. Scholarly interest in sexual orientation and queerness in Anglophone Caribbean literature has gained traction with the trailblazing Our Caribbean: A Gathering of Lesbian and Gay Writing from the Antilles (Glave 2008). ${ }^{1}$ Unfortunately, only a slowly growing number of studies pursue the example set by Keith B. Mitchell's "Naming that which Dare not to Speak: Homosexual Desire in Joseph Zobel's Black Shack Alley" (Mitchell 2002) or Omise'eke Natasha Tinsley in Thiefing Sugar: Eroticism Between Women in Caribbean Literature (Tinsley 2010),

1 See the online collaborative platform created by Angelique V. Nixon and Rosamond S. King: Theorizing Homophobias in the Caribbean-Complexities of Place, Desire and Belonging, www.caribbeanhomophobias.org (Nixon and King 2012). The online platform includes activist reports, critical essays, and interviews, as well as various type of media, and continues the work of Our Caribbean to offer a complex understanding of the Caribbean sexual landscape in the Americas and in a transatlantic context. 
which devotes one of its six chapters to French Caribbean literature. More recently, Jarrod Hayes dedicates an entire chapter of Queer Roots for the Diaspora: Ghost in the Family Tree (2016) to Martinican authors' stereotypical representation of the makoumè (pejorative French Creole term for homosexual man); as does Charlotte Hammond in Entangled Otherness: Cross-Gender Fabrication in the Francophone Caribbean (Hammond 2018). When present, "the description of 'the other' (and of any difference)—of sex and of sexual orientation - often appears amusing, crazy, not serious" in Francophone Caribbean literature (Spear 1995, p. 151). Beyond the mockery, derision, and dismissal, however, one can read the figure of the makoumè as an "analytical understanding of the complexity of masculinity and even its deconstructions" in Martinique (Hayes 2016, p. 47; Hammond 2018, p. 179). Similarly, the earlier portrayal of sexual orientation and queerness in the Haitian René Depestre's Le mât de cocagne (The Festival of the Greasy Pole, Depestre [1979] 1990) and "Blues pour une tasse de the vert" (Depestre [1990] 1993) ("Blues for a Cup of Green Tea") ${ }^{2}$ harbors richly symbolic content beneath its sometimes "amusing" or "not serious" surface, as he exposes a hegemonic, toxic masculinity inherited from colonialism and the homophobia it necessarily generates.

Questioning Depestre's hypersexualized imagery through a feminist, gendered lens reveals the sociopolitical implications of sexual and racial images in a Francophone transatlantic world, as well as, as theorized by Audre Lorde, the inextricable ties between racism, sexism, and homophobia (Lorde 2007, p. 110). In the short story "Blues", Depestre is the first Haitian (and probably the first French Caribbean) writer that we know of to "give voice", however briefly, to a homosexual character, defying simplistic categorization and not reduced to a mere stereotype. Depestre's two texts fuse comedy, farce, and serious political and socio-cultural commentary to show the mechanisms of power and fear generated by colonialism in a French transatlantic context. He thus exposes the multiple hidden facets of patriarchy and questions pedestrian notions of gender, race, and power in a postcolonial world. He engages with exuberant sexuality and a hypermasculinity inherited from the colonial period and illustrates the politics of desire of an author who in his works embraces an unapologetic activism and brazen carnality. In The Greasy Pole and "Blues", Depestre uses sexuality in an often satirical, humorous, and grotesque fashion to express his political views against oppression, which he explores in his essays (Depestre 1980, 1998), fiction (Jones 1981, p. 26; Depestre [1990] 1993, p. 153), and poetry (Depestre 1976; Jones 1981, pp. 23, 25).

If each work presents a fascinating homoerotic desire for the phallus (phallic homodesire), Depestre writes homosexuality differently in the novel than in the short story; in the two texts, though, he both deconstructs and reinserts gendered norms. In the novel, a group of men frenetically attempt to climb a wooden pole; in the short story, one man feverishly attempts to climb the flesh-and-blood pole of another reluctant, but somewhat tempted male. The Greasy Pole depicts a masculine competition and uses homosexuality as an allegory to denounce the castrating element of a postcolonial dictatorship; Depestre mocks both the figures of the individualist "man of action", the hero of the nation (heterosexual par excellence), and the tyrant (vector of castration and emasculation, namely homosexuality as a symbolic stand in for impotence). Through the humorous misadventures of a love triangle, "Blues" expresses a homophobia that can barely hide its fascination with the homosexual, all the while highlighting the idea of racial solidarity as a delusion. Eventually, though, in "Blues", for the flamboyant heterosexual protagonist, the best compliment for his masculinity is the desire of another man.

In both texts, Depestre valorizes what he terms "solar eroticism" (l'érotisme solaire) and "geolibertinage". The first neologism refers to a Caribbean expression of sexuality, free and joyful; the latter, its transnational and global expression. He has theorized in detail his vision of eroticism in his essays Bonjour et au revoir à la négritude (Depestre 1980) and Le métier à métisser (Depestre 1998), but also in some of his earlier poetic work (Roy 1976; Jones 1981), such as Poète à Cuba (Depestre 1976) (A Poet in $\mathrm{Cuba}$ ). While glorifying a black masculinity based on heterosexual, often polyamorous sexuality in a 
postcolonial milieu (Haiti) and a French diasporic space (Paris), this male-driven paradigm nonetheless depends heavily on female agency. Scholars often celebrate his solar eroticism as a source of black masculine and heterosexual salvation, as well as freedom from oppression in a transatlantic and global world (Roy 1976, pp. 8-9; Leconte 2016b, pp. 229-52). A few researchers question Depestre's representation of heterosexuality and critique his alleged sexism and machismo (Jones 1981, p. 29; Dayan 1986, pp. 581-95; 1993, p. 151; Carrol 1990, xliv; Munro 2007, p. 133). Ultimately, his portrayal of masculinity illustrates the ways in which colonialism has (mis)shaped ideas of sexuality and gender in the Caribbean and sheds lights on "populations where machismo and homophobia are cultivated as regulatory and repressive mechanisms", not only in the 20th century, but also in the 21st century (LaMothe 2017, p. 259). Homophobic violence that erupted during a same-sex ceremony and set a neighborhood on fire in Haiti in 2017 exemplifies this point (Chapman et al. 2017, pp. 143-59).

Despite Depestre's promotion of a distinctly Caribbean, liberating quest for sexual pleasures, the misadventures of his characters suggest the stifling pervasiveness and persistence of the European influence on Caribbean constructions of sexuality. Depestre's two texts, despite glorifying a Caribbean solar eroticism, at times present a very European construct that, eventually, confirms that "the domain of eroticism is essentially the domain of violence, the domain of violation" (Bataille 1957, p. 21). Such a framework also unveils the many faces of patriarchy and its mechanisms of control, which are "equally about the establishment and retention of power between races or ethnic groups, classes, and sexes" (Mohamed 2004, p. 64). Here, patriarchy thrives on hypersexuality and physicality (brute force). When associated with violence and homoeroticism, however, these two traits threaten the very masculinity that they underpin.

\section{Masculinity and Theatricality: The "Man of Action" and the Quest for the Phallus}

The Greasy Pole depicts a community at the end of the 1960s in a grim parody of Haiti under François "Papa Doc" Duvalier's dictatorship. The French title Le mât de cocagne, an ironic reference to the medieval land of Cockaigne-a delightful place where all is possible, pleasures abound, and sexual freedom is not restricted-supports such a reading. It is in fact a shortened version of Depestre's first novel, the Spanish-language El palo ensebado (1975), which Depestre wrote and published in Cuba in 1975, where he lived from approximately 1959 to 1978. The author's bitter disappointment with the Revolution, communism, and the Cuban regime pervades both the original version and the later reworking in French. Having lost Castro's support and cut ties with the Communist Party-whose evolution in the Americas and Europe left Depestre disillusioned (Leconte 2016a, pp. 235-38)-the one-time "revolutionary poet", rendered stateless by the Duvalier government, found himself branded an "enemy of the Revolution" in Cuba (Poinsot 2016, pp. 9, 22). For a time, he lived under quasi-house arrest there and found his saving grace looking into his past to write about Haiti (Poinsot 2016, p. 8). In his poetry from the Cuban years, even before he published El palo ensebado, Depestre also started to write about eroticism as a subversive, liberating force against oppression and tyranny. As such, he found inspiration in surrealism and its vision of love and sexuality (Carrol 1990, p. xvi)—particularly the notion of l'amour fou ("mad love"), which André Breton explored in his 1937 text of the same name-which Depestre had discovered (along with communism) during his stay in Paris. This passionate love, which for surrealists became "a force subversive to any order, an anarchical expression of individual desire" (Jones 1981, p. 28), struck a chord with the young Depestre. These early influences have informed his idea of "marvelous realism" (Depestre [1980] 1989, pp. 236-46); these influences also found expression in his Poète à Cuba (Depestre 1976) (A Poet in Cuba), in which he defines Comrade Eros, his "revolutionary libertine" (Jones 1981, p. 20). This archetype resurfaces in various guises throughout Depestre's oeuvre; notably as Henri Postel in both versions of Greasy Pole, and later as the geolibertine protagonist Stefan in "Blues". So central is physical love to Depestre's thought that he titles the second section of $A$ Poet in Cuba "Évangile selon Saint Éros" ("Gospel According to Saint Eros") (pp. 77-107); beneath the title, one can read an excerpt of the poem "Je t'aime" (1956) by the surrealist Paul Eluard. At one point, in Depestre's poem "Eros and Revolution", the poetic voice demands, "Comrade Eros/Make love and 
revolution" (Depestre 1976, p. 94). The sexual act constitutes an inherently political one; making love is simply one way of making revolution. The poetic voice explains, for instance, "Comrade Eros tells the world:/'I will not be the cuckold of socialism/The State, it is I/I fuck therefore I am'" (Depestre 1976, p. 95). For Depestre, already, "Eros may conceivably help to undermine capitalism" and bourgeois conventions (Jones 1981, p. 28). However, the Cuban authorities did not appreciate his representation of sexuality, his critique of how the regime restricted individuals, nor his exploration of the notion of race (Carrol 1990, p. xxv); they refused to allow the publication of A Poet in Cuba on the island in 1973.

Indeed, the deepening of Depestre's thoughts on the question of race, racial discrimination, and colorism $^{3}$, all inherited from the colonial system, date back to his time in Cuba (Bonniol 2016, para. 52, 55). Both incarnations of Greasy Pole not only recall Depestre's awareness of how the first black Republic failed to fulfill its historic promise because of an inability to create a truly cohesive Haitian nation (Bonniol 2016, para. 1, 5), the novels also recall his mistrust of any theorization of race, a mistrust inherited from the French world in the French Caribbean (Bonniol 2016, para. 6, 50-56), as one of the spokesmen for the tyrant Zachary affirms, "The Greasy Pole, for anyone knowing the history of the island will symbolize from today onward the force of the Black man, of the Maroon" (Depestre [1979] 1990, p. 46). The same character accuses Postel of being "the nigger without ancestors, whose words and conduct have always reeked of mulatto insincerity, hypocrisy, racism and liberalism" (p. 47). With his concern with "the eternal race prejudice" (p. 46) in Haiti, Depestre presents his vision of the tension between the former elite of color, often constituted of mulâtres (light-skinned Afrodescendants), and the new members of Duvalier's tyrannical regime, representatives of the noiriste movement. While the noiriste movement was initially supposed to promote pride in a common African past and African ancestry, it eventually embraced the same colorism as the mulâtres, simply with an inverted hierarchy, so that darker-skinned Afrodescendants held power, replacing the elite of light-skinned individuals.

The novel recounts the spiritual and political rebirth of the mulatre Henri Postel, "unrecognized champion of democracy" (Depestre [1979] 1990, p. 38), a born leader who had once participated in his small island's public life as a senator. He embodied an archetype of masculinity that recurs throughout Depestre's work: the "man of action", a man who never backs down and who expresses his desire for liberty and sexual gratification at any cost ${ }^{4}$. His pursuit of erotic love remains firmly inscribed within a political framework: sexual gratification does not equate to pleasure, but to power and control. Unfortunately, in retaliation for the political threat posed by Postel's popularity, the dictatorial regime has castrated him literally and symbolically by torturing and killing his pregnant wife (p. 47). By excising his sexual pleasure, they excise his power. By the novel's opening pages, Postel is but a shadow of his former self: a zombie. Eventually, he devises a plan to escape his island and seek refuge in Canada. While on his way to freedom, however, the ex-senator decides on an apparent whim to stay and participate in a sporting competition: the titular festival of the greasy pole, around which the novel's action centers.

Postel's portrayal as a "man of action", potential but fleeting incarnation of Comrade Eros, the one who makes love and revolution, remains fraught. If Depestre mocks his fictional tyrant Zachary, he also mocks Postel: the ex-senator's opponents repeatedly criticize his individualist desires. This contradiction between the personal and the political, heightened by their symbiosis, suggests that the purpose of Postel's quest might entail saving his ego as much as saving his compatriots. Why does Postel finally choose to call public attention to his presence? Initially, he refuses to acknowledge his project as a phallic quest, declaring "I will climb for the sake of climbing" (Depestre [1979] 1990, p. 35). Perhaps his name-old French for "post" - predestines him to such an undertaking. Or one may choose to view that his endeavor amounts to a quest for freedom and a way to return hope to

\footnotetext{
On colorism and its connection to colonialism, see (Hardwick 2014).

The short story "Boazhu", also from Éros dans un train chinois, depicts the prowess of such a man.
} 
the citizenry (Mbom 2016, pp. 149-64). One may even choose to view this novel as a "political parable" (Jones 1981, p. 25), a satire about a doomed "self-sacrificial struggle" dripping with dark humor and grotesque (Carrol 1990, p. xlvi). Ultimately, an examination of Postel's enterprise reveals the mechanisms of an exercise in futility fueled by a fear of castration and impotence that flirts with homophobia.

\section{From the Spiritual Poto-Mitan to the Grotesque Pole: Transfiguration of Masculine Power}

Organized by the island's despot, Dr. Zoocrate Zachary-a fictionalized version of Papa Doc Duvalier (Carrol 1990, pp. xxxiv-xliiii)—the tournament takes place in an outdoor amphitheater, with all the pageantry common to autocrats. Throughout the novel, the omniscient narrator mocks President Zachary, his followers, and the local and international press covering the festival for their obsession with the phallic aspects of the pole. This event offers a gendered performance that exposes the cracks in the dictatorship and encompasses a crucial homoerotic element. In this context, homoeroticism indicates desire for the same sex, rather than a sexual act per se. Indeed, the competitors express a masculine repressed desire not merely for someone else's penis, but more precisely for a phallus in its capacity as a symbol of power. In the public space of the tournament, the erection of the pole personifies Zachary's absolute power as noted by a local newspaper: "a Papa Phallus, a clear and evident organ, defying the palm tree, the breadfruit tree, in its glorious irruption toward the Sky Vagina of Freedom" (Depestre [1979] 1990, p. 63). In a story infused with vodou imagery, Depestre develops a complex nexus of symbolism surrounding the pole as it becomes what Lacan, revising Saussure, calls a floating signifier (Mehlman 1972). That is, while all of the characters agree on its semiotic importance, the specific meaning lies in the eye of the beholder.

The fluctuating meaning manifests in the dichotomy between the bokor (a vodou priest who often practices black magic), who works for the tyrant, and the manbo (a vodou priestess who only practices white magic and healing), who works for Postel. For the bokor, who represents the forces of darkness and death, the pole serves as a grotesque vector of toxic hypersexuality, homosexuality, and eventually castration and failure; for the manbo, who symbolizes goodness and life, the pole functions as a vector of a flamboyant heterosexuality and freedom, but even this success proves fleeting. If Sor Cisa, the manbo, demonstrates that the spiritual, too, has a sexual component and thus offers a kind of sexual healing, the pole remains a symbol of hypersexuality and toxic masculinity. Indeed, the festival is a satirical and irrelevant stand-in for a vodou ceremony; the greasy pole becomes a bastard version of the vodou poto-mitan (the pole in the middle of the room that supports the roof and is dedicated to vodou rites). Usually, in a vodou ceremony, the poto-mitan allows the practitioner to commune with the loas (spirits). Loas descend via the poto-mitan and take possession of the vodouisants, the vodou practitioners/worshippers. The ritual depends entirely on the crucial movement of descent and its denotation of the spiritual elements. In contrast, the novel valorizes the movement of ascent, of climbing the pole not to commune with the spirit, but to demonstrate one's individual masculinity and obtain the material reward hidden at the top.

The pole, an incarnation of totalitarian power, looks architecturally phallic, resembling an immense erection when planted in the ground, which betrays the phallocentrism of Zachary and his ilk-their celebration of a power associated with the erect penis. Yet this idea of power implies a defense mechanism hiding the fear of being unmasked as non-masculine, feminine, or homosexual (Nurse 2004, pp. 13-14). Here, Depestre uses homosexuality more as a signifier of supposedly non-masculine behavior than an indication of (homo)sexual identity per se. A night before the tournament, during a vodou ceremony, Zachary's official State priest (bokor) Gloomy-Simon-Seven-Days associates the president to the mast explaining, "In fact, your Excellency must descend with all the blood of the living man into the vegetal veins of the pole in order to be able to say: "This greasy pole, it is my State, it is myself!'” (Depestre [1979] 1990, p. 106). This parody of Louis XIV's apocryphal statement of his hegemony over France, "l'état, c'est moi", mocks Zachary's thirst for power. Gloomy-Simon-Seven-Days's proclamation also ironically echoes Comrade Eros's claim, "L'Etat, c'est 
moi, je baise donc je suis!," The State, it is I, I fuck therefore I am!" (Depestre 1976, p. 95); here emerges an indication of what happens when the Revolution goes wrong: the rise of an unrestrained, masculine, individualist ego that defines itself through its sexuality. The act of climbing the mast equates to nothing more than climbing Zachary himself.

This type of ideology originates in a masculine hegemonic discourse that promotes hyper-masculinity and homophobia: hostility born out of the fear of not being a man. In this symbolic order, homosexuality becomes the marker of castration and failed masculinity. It is not desire but behavior that defines the macici (a derogatory Haitian Creole term used by Depestre); he allows himself to be dominated by other men. Thus, a homosexual does not constitute a "man of action"; he can fulfill the role only of the feminized object being sodomized. Again, this ideology does not encompass the positive "active" masculinity of the homosexual man on top; through its distorting lens, homosexuality signifies only passivity (being taken). Here, the sodomizer, the one who penetrates, or the "man on top", and thus "the man of action", cannot by definition be homosexual (coded feminine) as he functions as the "active" and so masculine member of the coupling. Implicitly, this homophobic framework, which promotes the prowess of a heterosexual Don Juan, also constructs a phantasmagoric homosexual as a feminized and passive figure: a man without an erection. Such a man sees his sexual status reduced to that of a hole available for penetration by others (that is, "real" or heterosexual men or, metaphorically, the State).

Under the often mocking gaze of an assembled crowd, jury, and governmental dignitaries including Zachary himself, the competitors vie to climb a large tree trunk transformed into a smooth, slippery pole. Despite the physical prowess this requires, the athletic contest offers the ultimate proof not of manliness, but of emasculation. The game constitutes a mise-en-abyme $e^{5}$ of the social norms of the novel's fictional society: by metonymy, a phallic extension of a dictatorial state vector of castration. This competition itself provides a cathartic stand-in for armed battle, an impotent enactment of rebellion that is rigged so the would-be rebels can only lose. Desire for the phallus can only amount to desire to be penetrated by it, not to wield it. That is, at least, the only result possible in this system. Sor Cisa, a vodou priestess, supports Postel through the spiritual aspect of sexuality (Depestre's solar eroticism) and sees the pole's potential to revert to life (a positive heterosexual paradigm). She thus tries to redirect the once-impotent Postel to a more life-affirming, masculinity-enhancing desire; if the pole functions as a floating signifier, she tries to "point" him in the direction of her interpretation of it, not Zachary's. No wonder that, at the end of the novel, she dies in a rape-murder, torn apart as a soldier impales her with a monstrous phallus. To desire the phallus within Zachary's system can only result in death, whether intellectual or literal.

\section{Performativity and Mechanisms of Power: There Can Be Only One}

Like other totalitarian regimes, Zachary's government relies on the surveillance and control techniques used in prisons: the complementary, systematized sorts of gaze known as the panopticon and synopticon, theorized by Bentham (1791) and (Foucault 1975, 1995), among others. The panopticon refers to a circular building or system in which one authority figure located at the center observes and controls all the other individuals in the surrounding space. As the latter do not know whether or not they are being watched at any given time, they force themselves to conform to the expectation of the unseen watchman, thinking that they have no other options (Bentham and Bowring 1995, pp. 29-95). This structure multiplies the power of a single authority in a way that reduces a group of individuals to a collective, seemingly impotent mass. Moreover, the panoptic system stifles agency by effecting a "transformation of the soul". Prisoners, whether literal or metaphorical, internalize the watching Other and so participate in their own subjection through an acquired self-monitoring and policing (Mathiesen 1997, p. 216). In The Greasy Pole, Zachary terms this transformation "electrification of the

5 Self-reflexive embedding, as of a painting showing a painting of itself or a story within a story. 
souls", a euphemism for zombification and impotence. In this way, Depestre's dictator envisions his society as a kind of open-air prison:

I want to see Postel move about freely in the society of men [ ... ]. With my system, the zombification factor will be lodged inside Postel. [ ... ] Electrification of souls attains a new metaphysical dimension: a death resembling life more than anything else (Depestre [1979] 1990, p. 6).

In this fictional world, surveillance often shifts between the panoptic construction and the synoptic. Where the panopticon controls the crowd with the gaze of an authoritative figure placed in a central position, the synopticon establishes power through the gaze of a peripheral crowd riveted on a single figure in order to control that individual (Mathiesen 1997, p. 219). Architecturally, the enclosure in which the tournament takes place recalls classical Roman amphitheaters. The competition takes place at the Square of Heroes, where a dense crowd gathers around the erected greasy pole, a double line of armed soldiers separating them from the "arena" (Depestre [1979] 1990, p. 54). On one side of the open space sits a table for the jury that evaluates each performance, and on the other side is the competitors' bench. Beyond this inner circle stands the platform where Zachary and his zealots have a privileged view as they sit above the public. The crucial principle in the game remains the gaze of dominant power.

The panoptic and synoptic structures at the heart of the novel impose a type of surveillance and control that also dictates gender and racial norms through the symbolic enactments of sexual acts and triumphant masculinity. The tournament forces competitors to perform a prescribed and subjugated masculinity based solely on physicality, for all to see. The pole becomes a locus of representation, a theater where the climber plays the role of the "man of action" (strong man). However, in climbing the pole, the competitors participate in a metonymic form of onanism in which they mimic not only a hand-job, but full coitus. Their frenetic up-and-down movement becomes symbolic of the sexual pleasuring of Zachary. The outcome reaffirms State dominance; participants' agency remains illusory at best, their pleasure irrelevant.

In this controlled space, a subject climbing the pole, such as Postel, wrongly thinks that he can resist and subvert the establishment. One cannot participate in the tournament without participating in the hegemonic system of surveillance with both panoptic and synoptic characteristics, which Zachary has established for the humiliation and control of the competitors. Climbers play the role that the state has authorized and acquiesce to the process by which the dominant power eradicates potential threats. The ascent, which eventually signifies the forfeit of a triumphant masculinity, results above all in castration: being screwed by the system. Clovis Bartabog, the aide of the despot, warns climbers from the start that the winner will receive money and a prison sentence, or possibly even death.

Hence, considering the Square of Heroes as a site for a theatrical mise-en-scène that both reenacts and undermines the power structure allows for a discussion of the political implications of sexuality, gender, and performativity, to borrow Judith Butler's terminology. In Butler's framework, gendered attributes are performed and repeated to the point they appear to be inborn characteristics. The same can be said for race (Scheie 1998, pp. 17-29). As a theatrical space, the Square of Heroes showcases a castration ritual. It evokes areas officially dedicated to performance that may stand as spaces both averse to and created by the dominant system (Murray 1999, p. 90). This twisted theatrical space allows for the study of normative society and the construction and deconstruction of its dictums and gender codes.

The amphitheater around the post manifests the masculine and racial performativity of the structure inherited from the plantation system, the nefarious legacy of the West (Couti 2006, p. 50). The power struggles within and outside the arena manifest Depestre's awareness of Haiti's lack of inclusivity and inability to liberate itself from the lingering effects of colonialism in the guise of colorism and hatred of the citizens' African heritage (Bonniol 2016, para. 1, 5). The tension between the light-skinned Postel and Zachary's often darker-skinned followers echoes the historic tension between 
the mulatre elite and the people from the countryside. Like Duvalier, Zachary creates a cadre of noiriste supporters who exploit a purported African pride to dominate the masses, just as the mulattres had often done with their disdain for Africa. Despite its promise, the Haitian Revolution gave birth to political dissension based on colorism with the creation of Alexandre Petion's Republic (1806-1818) and Henri Christophe's Republic (1807-1811) and Kingdom (1811-1820). These regimes draw inspiration from a European vision of nationhood. This configuration incarnates the colonial and European heritage in the domination structures still existing in Haiti. The United States' occupation of Haiti from 28 July 1915 to 15 August 1934 and recurrent international interferences in its local affairs recall the political and racial precariousness of this independent Caribbean state. In the arena around the pole, just as in the plantation during the time of slavery, physical force is prized in (enslaved) workers: namely the black man-the darker-skinned individual. There is no expectation for intelligence; the commoner is reduced to nothing but his muscles and becomes a beast of burden or, here, a climber. The game also shows the pervasive colorism, the social hierarchy and preference organized according to a person's complexion. This colorism increased during the United States' occupation as American officials attempted to impose their vision of "separate but equal". It was often darker-skinned men, usually from the lower classes, "delinquent' and vagabonds" (Depestre [1979] 1990, p. 15), who participated in the festival of the greasy pole. Postel is a light-skinned man who used to belong to the dominant elite; the narrator emphasizes how dark all the other competitors are. As for the climbers' performances, they correspond to "spontaneous acts that questioned, but ultimately reinscribed, popular and official norms of sociolinguistic practice and sexual identity ... as a simultaneously rupturing and preserving force" (Murray 1999, p. 89). Despite Postel's subversive purposes, he stills participates in Zachary's system promoting the role of the emasculated man.

\section{Make Love and Revolution: Ephemeral Hope and Resistance}

The reader may prefer to believe that Postel regains his manhood away from the public space of competition and the gaze of Zachary and his ilk, in a very private space. In her house, Sor Cisa organizes a vodou ceremony for Postel. He himself becomes a pole upon which Elisa (Sor Cisa's cousin) stretches herself out in "the copulation of heaven and earth" (Depestre [1979] 1990, pp. 94-95). This "private" coitus stands as a counterpoint to the very public climbing of the greasy pole. These two depictions seem to oppose a manliness for show, performed for others in the public arena, and a manliness for the self, performed in a private space. This opposition evokes the distinction that Depestre makes between the Caribbean "solar eroticism" as a force of masculine liberation and the "Occidental Eros", which "looks as though it evolves under the constant menace of Thanatos" (God of Death) (Depestre 1998, p. 127). Depestre theorizes his vision as follows:

The pagan, solar side of my temperament as a Caribbean man immediately opposes my vision of love to the painful experience that has marked the historical adventure of the Occidental Eros. [ ... ] In the erotic culture that has my predilection, the woman blossoms as a garden of paradise in the arms of an enchanted farmer who passionately digs and plows her adorable depths. (Depestre 1998, p. 125)

The imagery evokes another of Depestre's archetypes, the sexualized femme-jardin (garden-woman) or "Hortensia [hydrangea] from the hills" (Depestre [1979] 1990, p. 51) and shows how the term "garden" becomes a euphemism for vagina. Depestre dedicated a whole book to the glory of this vision of woman, Alléluia pour une femme jardin (Depestre [1973] 1981) (Alleluia for a Garden Woman), also composed during his Cuban years. Depestre's eroticism champions a Caribbean sexuality in which pleasure as a part of Nature is the guiding principle that challenges death, a love ostensibly free of Western bourgeois and Western Judeo-Christian societal restrictions. The flamboyant prose cannot hide a restrictive, masculine conceptualization that reduces women to a vagina being plowed or penetrated for only male pleasure. The author thus recreates some of these same constraints in his "authentically Caribbean" paradigm. 
Elisa is, of course, a femme-jardin, a "fresh hortensia from the mountains" (Depestre [1979] 1990, p. 52). Though Elisa dances on his pole, Postel's sexual encounter reflects Depestre's concept of solar eroticism as male pleasure. Indeed, although one may think that Elisa is an active participant in charge of the sex act, their erotic pleasure has one function; as a part of a vodou ceremony, it aims to revive Postel physically and spiritually. As she descends his pole to straddle him, the energy of the loas is transmitted through her to Postel. In a sense then, Elisa does not simply participate in a sexual act, she serves as the cheval (the symbolic mounted horse), the medium by which the spirit can act in the human world. If Depestre values the political dimension of sexuality, so too does he value its spiritual dimension. Elisa provides a means to an end: not personal pleasure or orgasm, but sexual healing. In addition, Sor Cisa's house functions as another theatrical space in which masculinity is performed and judged. Before Postel can even prove his maleness between the legs of Elisa, it is Sor Cisa who confirms his virility in the early stage of the vodou ceremony. She "traced a cross of hot oil on his testicles", before declaring with a biblical resonance: "You are a new man! You are Henri Postel, the man that you are" (Depestre, p. 89; our italics). If Zachary has the power to destroy an individual's masculinity (imposing the role of the sexually passive partner), Sor Cisa, through the intermediary of Elisa, has the power to revive it (restoring him to the sexually active role). She takes on a divine role through the performative nature of her words. That is, she transforms Postel simply by stating that he is a new man. Her actions underscore how a woman measures and guarantees the performance of masculinity. The narrator emphasizes the theatricality of the ceremonial event in which the dancing Sor Cisa is also an "actress, author, character, and reciter of her realm of joy and pain" (Depestre [1979] 1990, p. 94). She is an active participant who also "observed the marvelous work of the couple" (Depestre [1979] 1990, p. 94). In a sense, Sor Cisa is more active than Elisa, as she is the one orchestrating the ceremony. She separates the couple and prevents them from climaxing so that Postel can save his sexual energy for climbing the pole.

Depestre's imagery of sexuality contains political claims and marked cultural undertones that highlight the ambiguities in masculine resistance and freedom in a Francophone postcolonial world (Couti 2006, pp. 55-56). As a renewed man of action (a man with an erection), Postel can finally climb the pole-and not passively, but as a rebel. His sexual activity allows him to reconnect with Caribbean womanhood as a life source and, by extension, his island (non-European) identity and the entire natural world. This paradigm opposes the garden-woman (Elisa, for example), the fertile locus of Caribbeanness, to the greasy pole of inherently corrupt Western power (Papa phallus). Depestre's vision of sexuality recalls another European conceptualization: "eroticism implies a claim of the instant against time, of the individual against the collectivity; it affirms separation against communication; it rebels against regulations; it contains a hostile principle to society" (Beauvoir [1949] 2011, p. 205). Here, Depestre's vision of Postel as potential Comrade Eros again resembles the surrealist conception of l'amour fou as an anti-bourgeois disruptive force, this time adapted to the Caribbean. The opposition of eroticism to societal order entails political aspects that in a Caribbean context comprise subversion and undermine a realm of domination inherited from the plantation structure. As an instrument of freedom from societal oppression, Depestre's solar eroticism is thus subversive, yet this subversion remains incapable of transcending gender biases. If Sor Cisa and Elisa, uniting the powers of the spirit world and the flesh, possess the ability to reinvigorate Postel so that he can again wield power, they nevertheless remain in the background, consigned to supporting roles.

When Postel succeeds in reaching the top of the greasy pole, he finds "a trophy", "the treasure that Bartabog mentioned" at the beginning of the game: a rifle that stands as another phallic symbol of the dictatorship (Depestre [1979] 1990, p. 132). Poised at this climactic brink, Postel laughs, an act analogous to an orgasm or petite mort (literally "little death"), foreshadowing his imminent death. His laughter announces both the challenge of succeeding at an impossible task and the absurdity of dying for his success in a rigged game. The novel's satire is manifested in that laughter, triumphant even in defeat; physical, spiritual, and political; eminently human. In response to Postel's successful performance, a sniper shoots him down, but not before Postel shoots and wounds Clovis Bartabog and Angel Zachary, the dictator's daughter. The arena remains a perverse theater where the dynamics 
of power coerce competitors into a doomed phallic quest. The participants, often men from the lower-classes or petty criminals, except for Postel, cannot resist demonstrating that they are real men. Ironically, owing to a faltering ego that they do not acknowledge, they cannot resist the lure of demonstrating their masculinity in the very space that prevents them from being men. This phallic quest makes evident the characters' desire for a hegemonic masculinity and the fear of becoming less than a man-homosexual.

\section{Abject Seduction: Questioning Black Masculinity}

In the short story "Blues for a Cup of Tea", homosexuality becomes the source of antagonism and anxiety between two black men, students meeting in Paris for a short period between 1947 and 1951 . Their confrontation suggests a clash of cultures, serving as a reminder that blackness is not a monolithic concept. In this story, the homodiegetic narrator Stefan Oriol explains, "The happy geolibertine that I was found himself subjected to the advances of someone of his own sex" (Depestre [1990] 1993, p. 104). This homosexual other is not a mere stereotype, like the makoumè found in the writing of Caribbean authors such as Raphael Confiant and Patrick Chamoiseau, but a full-fledged character with feelings and desires. Similarly, Depestre's character, imbued with a homosexual identity-not simply a propensity toward sexual domination by other men-stands in contrast to the men depicted in a short and violent passage in Dany Laferrière's 1997 work La chair du maître-capitalization on the book cover. Reflecting on his recently released novel, Laferrière considers that he might be the first Haitian to introduce "un truc d'homosexuel" ("gay stuff") (Sroka 1997, para. 16), because of his depiction of what he terms a homosexual sex scene, in which one man responds to another man's threat of rape by suddenly grasping his attacker's penis and spitefully giving him a hand job (Laferrière 2009, pp. 295-96). Today, Laferrière enjoys arguably greater renown than Depestre thanks to his descriptions of flamboyant heterosexuality, of which How to Make Love to a Negro without Getting Tired (Laferrière 2010) serves as a good example. However, Depestre explores homosexuality first and in a more complex way that questions the boundaries of Caribbean masculinity.

The short story "Blues" may seem out of place in Eros in a Chinese train (Depestre [1990] 1993), an erotic collection celebrating heterosexual love. Depestre qualifies that this selection of stories as "playful, funny" and constituting "the conclusion to my erotic phase, my celebration of women" (Dayan 1993, p. 143). In each story, the male protagonist has sex in various countries, different locales-though rarely in a bed, and in often humorous and irreverent fashion; no one and nothing can prevent the geolibertine from expressing his sexual freedom. At times, his sex drive endangers his life and he often barely escapes death. Initially, "Blues" appears to revolve around the exploits of the heterosexual Stefan Oriol, who lives in Paris with his young Czech girlfriend, Lida. However, upon closer examination, this story focuses on a strange love triangle created by the American William Fowler's interest in the Haitian Stefan. While the geolibertine's mixed feelings toward homosexuality include an attempt to reinforce his heterosexual male ego, they also show that the homosexual is a source of fascination. Eventually, the triad offers a wider vision of geolibertinage that is not restricted to binary oppositions such as colonial/anticolonial or homosexual/heterosexual. Depestre transcends sexual binaries and geographical boundaries to show-long before singer Janelle Monáe composed her 2017 pansexual anthem "Make Me Feel" - that sexual orientation involves feelings, not simply acts of domination and submission. Nonetheless, in Stefan's case, despite a mutual attraction and the feelings William arouses in him, he claims his unwillingness to cross sexual boundaries.

The theatrical aspect of space and the synoptic structure of power that dictate Depestre's construction of masculinity inform "Blues" from the beginning. The vestibule of an academic amphitheater at the Sorbonne replaces the athletic amphitheater of The Greasy Pole. At the beginning of the academic year, William, a Black American, enters the vestibule to face a group of students, including the Haitian Stefan, who are watching him. The homodiegetic narrator's gaze becomes a metonym for all the eyes on William. Stefan scrutinizes William with pleasure and wonders about his identity in a passage that underscores the close link between scopophilia and the synoptic gaze 
(Lyon 2006, p. 40). The Haitian finds him attractive and notices "the seductive smile of relief" on the newcomer's face upon seeing another black man (Depestre [1990] 1993, p. 94). Stefan appreciates William's knack for fashion, describing him as an "ebony playboy" with "the allure of an English lord" (Depestre [1990] 1993, pp. 94, 103). This masculinity admired here lies not in William's strong body or forceful personality, but in his dashing, refined appearance tied to British dandyism or the "Boston Brahmin" type ("du pur gratin de Boston") (Depestre [1990] 1993, p. 94).

Stefan continues trying to define William and, while doing so, constantly makes William into an Other and an object of his gaze. However, William others Stefan as well. The way these two black men "other each other", the way they fetishize each other, reminds the reader that blackness and masculinity encompass more diversity than either character anticipates. The Haitian Stefan and the American William are both foreigners in Paris; their color and their race, if not a certain communal history of slavery, seem to unite them. Nonetheless, their initial contact underscores their cultural differences. During their first exchange of pleasantries, Stefan introduces himself as such: "I am Haitian, Stefan Oriol". William revises-and complicates-the Haitian identity in his reply (quoted from the original to show the alternation of languages): "De Haïti, West Indies, Toussaint Louverture, wonderful man! Je suis William Fowler, Bill Fowler, de Harlem" (Depestre [1990] 1993, p. 94, italics in original). William's shifting between English and French linguistic codes indicates his excitement; the organization of this verbless clause further underlines as well the ways in which the American constructs the Haitian's identity.

William twice stresses Stefan's place of origin: the first Black Republic. The American reduces the Haitian's identity to the history of resistance embodied by Toussaint Louverture and, implicitly, by the Haitian Revolution (1797-1808). During their first discussion, the exclamation "wonderful man" may denote the American's admiration for Toussaint Louverture, the heroic Haitian figure, but also foreshadows William's attraction to Stefan. During their third encounter, William again notes that the Haitian is from the land of Toussaint Louverture and that he descends directly from the Black Jacobins (Depestre [1990] 1993, p. 111). By evoking the man who fought against Napoleon and European forces, William recalls the transitionary and revolutionary period between the slave colony and the postcolonial Republic, and as such, the anticolonial history of Haiti. William also evokes a black internationalism and pan-Africanism that praise the Haitian Revolution, and uses this event to express sympathy with an ideology of struggle against whiteness and its hegemony. These multifaceted movements have promoted the necessity to unite black Africans who suffered from colonialism and descendants of Africans displaced by slavery to fight against racism and capitalism. As for a fascinated William (a minority in his country), he associates Stefan with a forceful black man with dark skin (Toussaint) who fought against white colonists and promoted a triumphant blackness linked to hegemonic masculinity and power-even if only temporarily.

The ways in which the African-American introduces himself also complicate his own identity. He first underlines his duality as William/Bill, one name fitting for a refined dandy and the other a down-to-earth American. Stefan reinforces this dichotomy by calling his new acquaintance "Sir Bill". As a British term, "sir" has colonial nuances. In addition, while William identifies Stefan by his country of origin (Haiti), he presents himself as hailing from a black American neighborhood (Harlem). He thus creates a parallel and correspondence between a black country and a black neighborhood. He situates himself in a 1950s America that sees the struggle of black men still oppressed by segregation and American racism, an America where the Harlem Renaissance was born in the late 1910s and African American creativity continues to thrive. Jazz in Harlem was still very much in its prime in the 1950s. Stefan hopes to learn more about "le monde noir américain" from his new acquaintance (Depestre [1990] 1993, p. 97). He also notes his keen interest in black music and authors such as Langston Hughes and Countee Cullen. Stefan seems ignorant of the fact that these writers are rumored to have homosexual proclivities (West 2003, p. 162; Shucard 1984, pp. 70-71). 
Love Letter and Love Triangle: Inability to Define Homosexuality

The men's second encounter at the end of the semester, in which William behaves rudely to Stefan's Czech girlfriend, hints at the fact that these two black men do not share the same attitudes towards gender, race, and class. Stefan had met Lida in Czechoslovakia a year earlier, when she was just sixteen. It is during the men's third and final encounter a week after the second, however, that their antagonistic visions of race, manliness, and sexuality fully emerge. After reading a love letter in which William reveals his homosexuality, Stefan goes to the American's bedroom to confront him and defend Lida's honor. In his letter, William apologizes for his rudeness to Lida and recognizes his jealousy of her because of his love for Stefan. As such, Depestre is the first French Caribbean writer that we know of who gives "voice" to a homosexual character and allows this character to express his desire for another man. In his letter, William conveys his contempt for Lida, who for him is "one of those athletic and dishonest bitches from California" (Depestre [1990] 1993, p. 101). This remark suggests that he despises Lida as a supposedly wealthy member of the bourgeoisie. The reader cannot ignore the sexist, racist, and classist undertones of William's language. As for Stefan, he has trouble finding a proper definition for his homosexual admirer. After reading the letter, though he does not know what do with this ardent "déclaration d'amour" (p. 102), Stefan cannot help noticing that during his "more than two years of geolibertinage none of [his] female conquests had thrown in his mailbox such an ardent and powerful love letter" (p. 102). He tries to make sense of the American's homosexuality using a cultural reference close to his Caribbean culture: "Sir Bill is a macici, a golden maricon from Alabama" (p. 102). The pejorative Haitian Creole "macici" translates as a harmless figure of effeminacy, as does the Latin American maricón. Then, speaking on the phone with Lida, Stefan uses the French slang term "tante" (faggot), which baffles her, as its literal meaning is "aunt" (p. 102). Language fails the Haitian. Neither Spanish, nor Haitian Creole, nor French can translate William's sexual orientation. Stefan mocks William's "effeminate prose" in his letter (p. 102). Stefan-just like the crowd and Zachary in The Festival of the Greasy Pole-conceptualizes homosexuality as the opposite of "masculine".

Lida has a slightly different take on William's homosexuality. According to the young Czech, William's love letter reaffirms and glorifies Stefan's virility and geolibertinage. She sarcastically mocks William, claiming, "Your lord [William] is having a fit of jealousy. Your macho success is without borders. Congratulations, my love!" (p. 103). For Lida, only a true man can attract both men and women. While her joke seeks to reassure Stefan, she inadvertently expands his conception of homosexuality. She implies that the homosexual, like the makoumè of Creolist writing, remains a "boundary marker" (Hammond 2018, p. 179), a landmark to define real masculinity, namely that of the geolibertine. She in fact insinuates that the desire of the homosexual other reinforces the masculinity of the heterosexual man. Lida, like Sor Cisa in The Greasy Pole, derives value primarily from her capacity to judge the virile, masculine performance and to reassure a man —in this case, Stefan-of his manliness. The dependence on the feminine affirmation of manhood also suggests how easily heterosexual masculinity can be threatened; ironically, this paradigm posits that without woman, there is no man. Despite Lida's tongue-in-cheek reaffirmation, still at a loss, and not amused, Stefan goes to William's bedroom to confront the American he now perceives as a "dangerous dandy" (p. 103).

\section{Around a Cup of Green Tea: Blues for Forbidden Love}

Stefan does not immediately realize that black masculinity is not monolithic and that racial solidarity is a tricky concept. The revelation of the masculinity game unravels in "the wings": in Sir Bill's bedroom. In that room, a civilized William first offers Stefan a cup of tea before their discussion. Their polite conversation ends quickly in a short scuffle, during which William pins down Stefan in an armchair. Having voiced his love and passion in his letter, William, neither passive or effeminate, refuses to deny his desire. After trying in vain to kiss Stefan on the mouth, William straddles him, masturbating until he achieves a violent orgasm. The scene combines both the comic and grotesque as Stefan observes that his own penis remains safely tucked in his pants where Stefan cannot reach it because of a broken zipper that serves as "chastity belt" (Depestre [1990] 1993, p. 113). 
The intimate space of the bedroom becomes a grotesque space of masculine negotiation where the fear of emasculation arises. For a moment, the systems of domination-whether synoptic or panoptic-that prescribe a normative and restrictive masculinity collapse. Stefan experiences this momentary breakdown of the norm, William's transformation from "a dangerous dandy" (p. 103) characterized by effeminate mannerisms to a forceful homosexual and potential rapist, with a narcissistic crisis when faced with an unexpected behavior. Initially, during their short discussion over a cup of tea, the young Haitian defends his heterosexuality and recounts his sexual exploits with a white French woman on a boat from the United States to France, where he enjoyed a first-class cabin and freedom from racial discrimination. Though aware of racism, he asserts that racial and social differences cannot restrain his sexual liberty and agency-two themes intimately linked in Depestre's writing. When William tries to create an atmosphere of intimacy by evoking their shared experiences of racism, Stefan replies:

I have never had any illusions on the subject. A young man hungry for culture, I sat to the right of the commander of a steamship, in the company of a steamship, in the company of eminent members of the French intelligentsia. Love was also a part of it. The power dynamics were in my favor. (Depestre [1990] 1993, p. 111).

Geolibertinage is politically revolutionary, as it entails a transnational identity and freedom from all societal constraints, even racial ones. If the concept of a "Comrade Eros" exulting in love and revolution remains rooted in an island (initially Cuba), with Stefan, Depestre offers a different, sexualized vision of black internationalism than the one expounded by the ideologies of American thinkers such as W. E. B. Du Bois, the New Negro Movement, Paul Robeson, Malcolm X, Martin Luther King, Jr., or the Black Panther Party, among others, or by French Caribbean thinkers such as the Nardal sisters or Aimé Césaire (Edwards 2003; Boittin 2010).

The traveling Haitian in Depestre's story considers solar eroticism to be a liberating force. Between the legs of the desired woman, preferably white, the geolibertine brings forth his transnationalism, as he is at home anywhere, despite racial and moral dictums. He perceives that his love-making to white women can be seen as a challenge to dominant power and proof that colonialism did not emasculate the black man. His womanizing typifies a particular logic linked to colonialism. As early as the 1930s, the African American anthropologist Eslanda Goode Robeson, wife and business manager of the civil rights activist, singer, and actor Paul Robeson, described Paris as a favored sexual playground for interracial relationships between black men from former French colonies and white women. She explains: "Negro boys often have great success, and are sometimes lionized by the French girls; the mulatto is often successful too" (Robeson 1936, p. 10). In so doing, she highlights the sexualized aspects of black internationalism in a Paris that can be considered as a diasporic and transnational space in which men of color fulfill their fantasies about sleeping with white women, taking advantage of them while deriving great masculine pride. Stefan shares the same masculine satisfaction. Once again, Depestre's construction of sexuality is not simply playful; it is a question of power. For the Caribbean geolibertine, the world (not merely the Antilles) is more than a heterosexual playground; it provides a space for the proclamation of one's worth.

According to the American, the Haitian does not understand race and power relationships in the world that surrounds him, as "there is nothing more hypocritical than the Whites" (Depestre [1990] 1993, p. 111). William's snide remarks deny the validity of a French Caribbean virility that can transcend national and racial boundaries. He minimizes Stefan's amorous exploits around the globe with white women. However, as Depestre's creation, William's construction of black internationalism or blackness in general does not represent the ways most black American intellectuals would understand these concepts. His construction of sexuality is also tied to a dynamic of power and colonialism that shows a problematic relationship with whiteness. William's homosexual desire results in an exotic understanding of the geolibertine's sex appeal. As he tries to forcibly grab the young Haitian's genitalia, the American confesses, "I love your sparkling marron [run-away slave] eyes, your incendiary hands of colonial plantations, your big magic dick that deflowers white adolescent girls" (Depestre [1990] 1993, p. 112). The interpolation of the English "darling" in the original French 
text suggests that William wants to create some type of intimate connection with the man he loves; arousing his anger provides the means to do so. Like Lida suggested earlier, William seems to find Stefan's heterosexuality, and thus supposed (brutal) masculinity, irresistible. However, the motif of the arsonist run-away slave, thirsty for white blood and white virgins, reduces Stefan to an old colonial stereotype: the hypersexualized black man. Such a racialization and sexualization usually belongs to white Western discourses around hegemonic masculinity (Nurse 2004, p. 9). William hints at the possibly sordid character of Stefan's relationship with the seventeen-year-old Lida and depicts the Haitian as a sexual predator. Although William underscores Stefan's sexual preference for minors as an attack against whiteness, he also emulates white supremacist discourses in doing so. He borrows the colonizer's gaze, but then turns it back around to eroticize the Haitian, celebrating rather than demonizing his rapacious sexual appetite. In this way, the American appears westernized-and thus corrupted-unlike Stefan, an "authentically Black" man from a Black country.

To make sense of William's desire, Stefan pretends that the American is playing a role with these mannerisms, and thus interjects: "Stop your play-acting, sir" (Depestre [1990] 1993, p. 110). Stefan realizes too late that there are various types of manhood, just as there are many types of cultural codes. If society offers "many masks that men might wear in their quest for masculinity" (Mohamed 2012, p. 505), Depestre's novel shows the danger inherent in a man's decision to unmask himself. The geolibertine discovers that Sir Bill shares nothing in common with his preconceived notion of the feminine figure of the macici. The terms the Haitian uses to associate his admirer's homosexuality with femininity and passivity do not apply to Sir Bill. This man of his race has taken advantage of their "racial solidarity" and the trust it entails to breach an unspoken contract.

Twice, the American physically prevents his guest from leaving his bedroom. The first time, when the Haitian stands up to leave, William coerces him into sitting down to drink his tea (Depestre [1990] 1993, p. 110). The second time, William forces the Haitian to submit to his sexual touches, which end in his masturbating while lying on top of him. After trying to defend himself by striking the aggressor, Stefan acknowledges his defenselessness: "Pinned deep in the armchair, I was completely at the mercy of his athletic strength" (Depestre [1990] 1993, p. 112). William's homosexuality and physique do not render him feminine; his behavior remains hypermasculine and threatening.

\section{Who's the Man?}

The narrative repeatedly complicates William's masculinity, frustrating Stefan's and the reader's attempts to contain it within circumscribed boundaries. For instance, when William tells Stefan to show him "Miss Pauline Bonaparte's throbbing black member" (p. 112), he implies that the Haitian's triumphant black penis amounts to nothing but a "tool" dedicated to a white woman's pleasure. This reification reinforces Stefan's victimization and castration. William's words undermine usual constructions of race and gender. By implicitly equating himself with a white woman, however, the queering of that particular commentary offers another story. The imperial French princess Pauline, Napoleon Bonaparte's sister, has gained a scandalous reputation for utilizing her power and her social position to engage in sexual "relations" with well-endowed black men (often slaves), a propensity that highlights the power relationship inherited from the colonial world (Depestre [1990] 1993, p. 210; Dayan 1995, p. 247). Alejo Carpentier's El reino de este mundo (The Kingdom of this World, Carpentier 1949) delves into her supposed nymphomania and love for big black penises. In a hypermasculine and traditionalist discourse, such behavior is everything but "lady-like" and "feminine". William presents Pauline as another sexual predator (masculinized if not masculine) who is more powerful than the emblematic black rapist. With his spiteful portrayal of this white woman, he thus perpetuates a sexist, misogynistic rhetoric. In addition, the way William sexualizes her presents her as a symbol of a patriarchal and colonial masculine power as she incarnates the sexual side of colonialism. However, as he desires her "throbbing black member", despite his visible blackness, because of his phallic desire, his words associate him with a masculine and colonial force of domination, and once again he emulates white supremacist discourses such as the ones at play 
during the United States' occupation. In Depestre's transatlantic world, the homosexual man signifies Western corruption. Therefore William, in a sense, represents a domineering Other to be feared.

The notion of William and Stefan as potentially similar sexual predators questions the societal validity of sexual and gender dictums. Nonetheless, the Haitian is the only one to consider himself a victim of sexual violation. To distance himself from his victimization, Stefan's mind leaves his body to observe the aggression as is common in cases of trauma, for the individual can only maintain agency outside of the body. Yet the scene of the attempted rape reveals a homoerotic moment in which the Haitian shifts the responsibility and blame for homosexual desires from William onto his own fascination:

Prostrate with horror and disgust at the touch of male flesh, I had the urge to call for help. But another emotion, as pressing as fear and repulsion, froze my voice. There was no heightened wickedness in the eyes of my aggressor. They were drowned in a sort of supplication, on the verge of tears. Their tenderly sensual radiance bore a hole in the icy armor of my male being. Might there be an Achilles heel in me whose existence I had not known of until now? (pp. 112-13)

Stefan poetically translates an intense moment of Kristevan abjection as he outlines his crisis; Kristeva explains that "abjection is [ ... ] some kind of narcissistic crisis: it is the witness to the ephemeral aspect of the state called narcissism" (Kristeva 1982, p. 14). William's sexuality threatens the Haitian's masculine identity at its core when his body and mind betray him while under sexual assault by another man. Some readers may choose to wonder why the Haitian does not call for help, as he fleetingly wishes to do. However, he acknowledges that the manifestation of his mixed feelings and potential weakness matter more. William's silent plea does not elicit a denunciation of effeminacy. Rather, the American's distress and tender sensuality touch Stefan so deeply that he doubts his own maleness (heterosexuality), if only for a moment. The effects of the "unknown emotion" taking hold of Stefan go beyond physical force and signal that the Haitian is seduced in spite of himself. The horrified Stefan is not ready to recognize that their embrace, though coerced, transcended mere power dynamics. Intrigued and curious, the Haitian participates to a small extent in his "molestation".

Throughout the attempted rape, the description of passion, lust, and desire is ambivalent and points more often than not to Stefan's ego and his irresistible geolibertine charms. As an observer, Stefan cannot help but remark while watching William's orgasm, "No woman, straddling my sword, has ever been seized by a tremor as violent as the one which contorted that man at the moment of his pleasure" (Depestre [1990] 1993, p. 114). As with his reaction to the steamy love letter, Stefan highlights William's intensity, not his weakness or femininity. This purported victim relishes the desire and ecstasy he inspires in another man. In this way, he echoes Lida's assertion that William's homosexual desire for him serves as the ultimate confirmation of his virility. For Lida, only a true man can attract both men and women. While another man's desire for him may flatter his ego, it is only in refusing his own reciprocal desire that the Haitian can resolve his narcissistic breakdown.

His "flesh, humiliated and offended", Stefan initially attempts to resist William's groping. Yet he gives in, defeated by an internal force stronger than his conscious will: "it [his flesh] seemed ready, in some way, to help assuage the sexual angst that crushed it with its weight" (p. 113). For him, his flesh, not his mind, wants to relieve his aggressor; this distinction allows Stefan to avoid confronting any homoerotic desire that he might repress. The underlying argument that his pleasure and complicity in the situation result from narcissism proves more convincing to Stefan than the idea that they originate from actual sexual desire for his aggressor. However, a lingering doubt remains; Stefan manages to accept his predicament by recasting it as a confirmation of his ability to evoke desire. It is no wonder that after William's orgasm, Stefan takes to his heels. Escape is the only solution, and he runs to Lida's place, where he spends the whole night having heterosexual sex with her to reassert his manhood. Just as for Postel with Elisa, coitus is not about pleasure; Stefan plunges into his girlfriend to re-masculinize himself. In this way, although their solar eroticism fails to acknowledge women as equals with a valid claim to power and pleasure, both men depend upon 
women to restore their masculinity after it has been damaged by Westernized (corrupted) black men. Stefan's rejections of William's homosexuality do not prevent him from being captivated by what he considers a transgressive act. Stefan's fascination, desire, and fear reveal that the homosexual is dangerous not as a potential rapist, but as an enticing seducer.

\section{Conclusions}

Depestre's The Greasy Pole and "Blues" both exemplify how works of fiction may "position manhood as an unfinished project" (Mohamed 2004, p. 490) and lead readers to wonder what it means to be a (Caribbean) man, an individual from a former colonized space. As such, studying these two texts enriches Queer and Gender Studies, while recalling the complexities of French Caribbean literature. If Postel, as a man of action, can embody the poetic Comrade Eros, "mak[ing] love and revolution", his subversive stance is fleeting. The revolutionary component of solar eroticism allows the hero to enjoy his victory for a short bout of laughter, a symbolic orgasm. If sexuality in the novel is inherently political, it is also inherently spiritual. However, when one grasps The Greasy Pole as a political satire, one realizes that Postel's quest in fact exposes an individualism gone wrong. Not only does Postel die, but most people who helped him also meet with a brutal, gruesome demise. In a sad irony, Postel amounts to little more than an inverted image of Zachary. That being said, Elisa survives to tell his glorious story of resistance. For Stefan, the answer lies in his identity as a glorified geolibertine, the epitome of the well-endowed black man who finds his sense of self between white women's legs. However, his sympathy with William's feelings demonstrates how easily a man can cross gendered boundaries once he acknowledges forbidden emotions. Lida serves to remind him of his hegemonic masculinity and his status as a geolibertine. He must live with the knowledge that no woman has ever written a love letter to him as William did or experienced an orgasm on top of him with William's abandon, joy, and intensity. William remains a dangerous dandy because he is so seductive. Just like Postel, however, Stefan remains a prisoner of a simultaneously colonial and post-plantation vision of the black man reduced to his physicality and sexuality. The misadventures of these characters demonstrate the quasi-impossibility of forgoing without the Western Eros and the dark and violent eroticism it encompasses. Comrade Eros seems to prevail if only for a moment. Depestre's solar eroticism does not merely entail personal enjoyment or the celebration of women, but also encompasses a fear of castration. This anxiety lies at the core of Depestre's construction of a normative, hegemonic masculinity, as well as threatening, seductive homosexuality. Depestre toys with a hypermasculinity that presents the many faces of patriarchy and destabilizes common ideas of gender, race, and power in a postcolonial world. In the end, what stands out is the dread of having to redefine oneself, one's manhood, and thus one's social bearings, but also the irresistible temptation to cross boundaries that should not be crossed, no matter how alluring.

Author Contributions: Conceptualization, J.C. and J.C.G.; writing—original draft preparation, J.C. and J.C.G.; writing-review and editing, J.C.

Funding: This research received no external funding.

Conflicts of Interest: The authors declare no conflicts of interest.

\section{References}

Bataille, Georges. 1957. L'érotisme. Paris: Les Éditions de Minuit.

Beauvoir, Simone. 2011. The Second Sex. New York: Vintage Books. First Published in 1949 in French.

Bentham, Jeremy. 1791. Essay on Political Tactics: Containing Six of the Principal Rules Proper to Be Observed by a Political Assembly in the Process of Forming a Decision, with the Reasons on Which They Are Grounded, and a Comparative Application of Them to British and French Practice: Being a Fragment of a Larger Work, a Sketch of Which Is Subjoined. London: T. Payne.

Bentham, Jeremy, and John Bowring. 1995. The works of Jeremy Bentham. Bristol: Thoemmes. 
Boittin, Jennifer Anne. 2010. Colonial Metropolis: The Urban Grounds of Anti-Imperialism and Feminism in Interwar Paris. Lincoln: University Press of Nebraska.

Bonniol, Jean-Luc. 2016. Entretien avec René Depestre. Available online: http://classiques.uqac.ca/contemporains/ bonniol_jean_luc/Entretien_avec_Rene_Depestre/Entretien_avec_Rene_Depestre_texte.html (accessed on 26 August 2019).

Carpentier, Alejo. 1949. El reino de este mundo. México: E.D.I.A.P.S.A.

Chapman, Dasha A., Erin L. Durban-Albrecht, and Mario LaMothe. 2017. Nou Mache Ansanm (We Walk Together): Queer Haitian Performance and Affiliation. Women \& Performance: A Journal of Feminist Theory 27: 143-59.

Carrol, F. Coates. 1990. Introduction. In The Festival of the Greasy Pole. Charlottesville: Caraf Books/University of Virginia Press, pp. xv-li.

Couti, Jacqueline. 2006. Au sommet du mât: érotisme et masculinité dans Le mât de cocagne de René Depestre. Cincinnati Romance Review 25: 45-63.

Dayan, Joan. 1986. Hallelujah for a Garden Woman: The Caribbean Adam and his Pretext. French Review 59: 581-95.

Dayan, Joan. 1993. Interview with René Depestre. Yale French Studies 83: 136-53. [CrossRef]

Dayan, Joan. 1995. Haiti, History, and the Gods. Berkeley: University of California Press.

Depestre, René. 1981. Alléluia pour une Femme-Jardin. Paris: Gallimard. First published in Canada in 1973.

Depestre, René. 1990. The Festival of the Greasy Pole. Charlottesville: Caraf Books/University of Virginia Press. First published in 1979 in French.

Depestre, René. 1989. Le réel merveilleux haïtien. In Bonjour et au Revoir à la Négritude. Paris: Seghers. First published in 1980.

Depestre, René. 1993. Blues pour une tasse de thé vert. In Éros dans un Train Chinois. Paris: Éditions Gallimard, pp. 93-114. First published in hardback in 1990.

Depestre, René. 1976. Poète à Cuba. Paris: Editions Pierre Jean Oswald, pp. 5-13.

Depestre, René. 1980. Bonjour et au Revoir à la Négritude. Paris: Laffont.

Depestre, René. 1998. Le Métier à Métisser. Paris: Stock.

Edwards, Brent Hayes. 2003. The Practice of Diaspora: Literature, Translation, and the Rise of Black Internationalism. Cambridge: Harvard University Press.

Foucault, Michel. 1975. Surveiller et punir: Naissance de la prison. Paris: Gallimard.

Foucault, Michel. 1995. Panopticism. In Discipline and Punish: The Birth of the Prison. New York: Vintage Books, pp. 195-228.

Glave, Thomas. 2008. Our Caribbean: A Gathering of Lesbian and Gay Writing from the Antilles. Edited and with an Introduction by Thomas Glave. Durham: Duke University Press.

Hammond, Charlotte. 2018. Entangled Otherness: Cross-Gender Fabrications in the Francophone Caribbean. Liverpool: Liverpool University Press.

Hardwick, Louise. 2014. Creolizing the Caribbean 'Coolie': A Biopolitical Reading of Indian Indentured Labourers and the Ethnoclass Hierarchy. International Journal of Francophone Studies 17: 397-419. [CrossRef]

Hayes, Jarrod. 2016. Queer Roots for the Diaspora: Ghosts in the Family Tree. Ann Arbor: University of Michigan Press.

Jones, Bridget. 1981. Comrade Eros: The Erotic Vein in the Writing of René Depestre. Caribbean Quaterly 27: 21-30. [CrossRef]

Kristeva, Julia. 1982. Power of Horror: An Essay on Abjection. New York: Columbia University Press.

Laferrière, Dany. 2009. La chair du maître. Roman and Paris: Editions du Rocher.

Laferrière, Dany. 2010. How to Make Love to a Negro without Getting Tired. Vancouver: Douglas and McIntyre.

LaMothe, Mario. 2017. Our Love on Fire: Gay Men's Stories of Violence and Hope in Haiti. Women E Performance: A Journal of Feminist Theory 27: 59-270.

Leconte, Franz-Antoine. 2016a. Depestre: Du chaos à la civilization de l'éros. In René Depestre: Du Chaos Haïtien à la Tendresse Debout. Paris: L'harmattan, pp. 229-52.

Leconte, Franz-Antoine. 2016b. René Depestre: Du Chaos Haïtien à la Tendresse Debout. Paris: L'harmattan.

Lorde, Audre. 2007. The Master's Tools Will Never Dismantle the Master's House. In Sister Outsider: Essays and Speeches. Trumansburg: Crossing Press, pp. 110-13.

Lyon, David. 2006. Synopticon and Scopophilia: Watching and Being Watched. In The New Politics of Surveillance and Visibility. Edited by Ray Ericson and Kevin D. Haggerty. Toronto: University of Toronto Press, pp. 35-54. 
Mathiesen, Thomas. 1997. The Viewer Society: Michel Foucault's 'Panopticon' Revisited. Theoretical Criminology 1 : 215-34. [CrossRef]

Mbom, Clement. 2016. La conquête de la liberté. In René Depestre: Du Chaos Haïtien à la Tendresse Debout. Paris: L'harmattan, pp. 149-64.

Mehlman, Jeffrey. 1972. The 'Floating Signifier: 'From Lévi-Strauss to Lacan. Yale French Studies 48: 10-37. [CrossRef]

Mitchell, Keith B. 2002. Naming That Which Dare Not Speak: Homosexual Desire in Joseph Zobel's La Rue Cases-Nègres. In Rhetoric of the Other: Lesbian and Gay Strategies of Resistance in French and Francophone Contexts. Edited by Martine Antle and Dominique Fisher. New Orleans: University Press of the South, pp. 115-30.

Mohamed, Patricia. 2004. Unmasking Masculinity and Deconstructing Patriarchy: Problems and Possibilities with Feminist Epistemology. In Interrogating Caribbean Masculinities: Theoretical and Empirical Analyses. Edited by Rhoda Reddock. Kingston: University of the West Indies Press, pp. 38-67.

Mohamed, Patricia. 2012. The Harder They Fall: Masculinity and the Cinematic Gaze. In Love and Power: Caribbean Discourses on Gender. Edited by V. Eudine Barritteau. Kinsgton: University of the West Indies Press, pp. 488-513.

Munro, Martin. 2007. Exile and Post-1946 Haitian Literature: Alexis, Depestre, Ollivier, Laferrière, Danticat Depestre. Liverpool: Liverpool University Press.

Murray, David A. B. 1999. Cultural Scripts of Language and Sexuality in Martinican Theater: The Improvisational Impasse. Cultural Anthropology 14: 88-110. [CrossRef]

Nixon, Angelique V., and Rosamond S. King. 2012. Theorizing Homophobias in the Caribbean-Complexities of Place, Desire and Belonging. Available online: www.caribbeanhomophobias.org (accessed on 10 May 2019).

Nurse, Keith. 2004. Masculinities in Transition: Gender and Global Problematique. In Interrogating Caribbean Masculinities: Theoretical and Empirical Analyses. Edited by Rhoda Reddock. Kingston: University of the West Indies Press, pp. 3-37.

Poinsot, Jérôme. 2016. René Depestre Hadriana dans tous mes rêves: Étude critique. Paris: Honoré Champion.

Robeson, Eslanda Goode. 1936. Black Paris, II. Challenge: A Literary Quarterly 1: 9-12.

Roy, Claude. 1976. Préface. In Poète à Cuba. Paris: Editions Pierre Jean Oswald.

Scheie, Timothy. 1998. Addicted to Race: Performativity, Agency, and Césaire's A Tempest. College Literature 25: $17-29$.

Shucard, Alan R. 1984. Countee Cullen. Boston: Twayne Publishers, pp. 70-71.

Spear, Thomas. 1995. Jouissances carnavalesques: représentations de la sexualité. In Penser la Créolité. Edited by Madeleine Cottenet-Hage and Maryse Condé. Paris: Karthala, pp. 135-52.

Sroka, Ghila. 1997. Dany Laferrière, La chair du maître (Entretien). May 14. Available online: ile-en-ile.org/danylaferriere-entretien-ghila-sroka/ (accessed on 26 August 2019).

Tinsley, Omise'eke Natasha. 2010. Thiefing Sugar: Eroticism between Women in Caribbean Literature (Perverse Modernities). Durham: Duke University Press.

West, Sandra L. 2003. Langston Hughes. In Encyclopedia of the Harlem Renaissance. Edited by Aberjhani and Sandra West. New York: Checkmark Books.

(C) 2019 by the authors. Licensee MDPI, Basel, Switzerland. This article is an open access article distributed under the terms and conditions of the Creative Commons Attribution (CC BY) license (http://creativecommons.org/licenses/by/4.0/). 